\title{
PRODUCTION OF HIGH QUALITY BEEF IN ACCORDANCE WITH EUROPEAN TRENDS ${ }^{1}$
}

\author{
S. Aleksić, M. M. Petrović, B. Miščević, V.Pantelić, Dušica Tomašević, Dušica Ostojić2
}

Contents: In our country, fattening of cattle is mainly based on heads of Domestic Spotted breed. Future of Serbian export of meat is first of all in production of beef of such quality which satisfies the demand and requirements of the market. In this regard and based on previous experiences of production for known buyers and according to their demand/request beef was exported to Italian, Greek and remaining markets. Prerequisite for any export of beef from Serbia is: identification and registration of all heads of cattle on the territory of the Republic of Serbia, application of international standards of control and monitoring of the production process and application of EU regulations relating to animal welfare.

Beside mentioned conditions it is also necessary to provide high quality fattening material - female calves for production of "baby beef" type and male calves for prolonged fattening. Contrary to increased demand for fattening heads of cattle, there is trend of decrease of number of cattle for fattening, especially calves and young cattle. One of the ways for efficient and fast production of high quality calves for fattening is application of the method of industrial crossing of Domestic spotted cattle of lower productive traits. Based on obtained results and realized economical effects we can recommend that method of industrial crossing should include $20-25 \%$ of female population of Domestic Spotted breed. The quality of meat obtained from crosses of F1 generation will fully satisfy requirements of consumers, especially those who have been traditional importers of our beef (Italy and Greece).

Key words: cattle, EU regulations, stress, crossing, breed, economical effects

\section{Introduction}

Our country was well known as exporter of beef to European countries, especially to Italy and Greece. Export of beef was expanding until Italy (1974) and Greece (1980) became members of the European Economical Community. For example, in 1974 we exported 50.500 t/year to Italian market and in year 1980 51.310 t to Greek market (Tojagić et al., 1989) and there were 25 registered slaughter houses with EU certificate. Today there are only two such slaughter houses (Knjaževac and Čajetina) with EU certificate and allowed quota of $9.984 \mathrm{t}$ of beef which we are not capable of realizing.

\section{Possibility of marketing of beef}

Future of Serbian meat export is in the production of beef of such quality which would satisfy and meet all requirements of the market. In this regard and based on our previous experience and practice in production of beef for already known buyers and in accordance with their requests, direction of export could be following:

1. Export to traditional Italian markets

Italian market demands high quality of beef. The Italy's most developed province Toscana demands so called "baby beef" quality. This is meat from young cattle not older than one year and average live weight of $450 \mathrm{~kg}$ - bulls and $400 \mathrm{~kg}$ heifers.

There is special interest on this market for meat of "baby beef" quality from female high quality young cattle. In regard to quality of meat pink colour of meat is demanded, equal marbling and fat tissue of white to light yellow colour. In regard to processing, mainly sides of beef (round + loin - back part/rump with

\footnotetext{
1 Review paper supported by the Ministry of Science and Environment Protection, Project no. TR6887B - Revijalni rad je finansiran od strane Ministarstva za nauku i zaštitu životne sredine Projektom broj: TR6887B

2 Dr Stevica Aleksić, scientific counselor, dr M. M. Petrović, scientific counselor, dr B. Miščević, scientific counselor, mr V.Pantelić, research assistant, mr Dušica Tomašević, research asistant, Grad.eng. Dušica Ostojić, research trainee, Institute for Animal Husbandry, Belgrade-Zemun
} 
6 ribs) and equally cut quarters. Equally cut quarters or compensated was could be marketed in limited quantities which also confirms the choosiness of this market.

2. Export to traditional Greek markets

Greek market as traditional importer of our meat demands meat from bulls slaughtered with over 500 $\mathrm{kg}$ of live weight and carcass weight of over $250 \mathrm{~kg}$. In regard to processing on this market compensated equally cut carcass or carcasses are demanded. Carcasses of good conformation and covered well with fat tissue are in demand on this market.

3. Other markets

Other markets for marketing of beef from Serbia are mainly markets of the countries of Near and Middle East. Requests on these markets relate mainly to religious way of slaughtering of animals and in regard to quality - traits of quality emphasized on Italian and Greek markets are not insisted upon here.

\section{Prerequisites for export of beef}

Today, our farmers and meat industry firms are very much interested in returning to markets of EU countries, however serious obstacle is that EU regulations on housing and transport conditions, as well as slaughter house depot and slaughtering are still not applied in Serbia.

Prerequisites for export of beef are:

1. Identification and registration of all heads of cattle on the territory of Republic of Serbia.

2. Application of international standards of control and monitoring of the production process.

3. Application of EU regulations on animal welfare.

- Identification and registration of all heads of cattle on the territory of Republic of Serbia. This is condition sine qua non, therefore the Ministry of Agriculture of Republic of Serbia has made the Regulation on identification and registration of cattle in 2004 (Regulation, 2004). One of the conditions for export of beef has been fulfilled.

- Implementation of international standards of control and monitoring of production process includes first of all implementation of HACCP (Hazard Analyzed Critical Control Point), GMP (Good Manufactory Practice) and GVP (Good Veterinarian Practice).

- Application of EU regulations relating to animal well fare «Protocol on protection and welfare of animals - OJ 340/97《

- Application of EU regulations relating to welfare of farm animals (O J L323/78, O J L221/98, O J L019/2000) especially calves - directives relating to minimum space provided for animals (O J L340/91, O J L025/97, O J L076/97)

- Application of EU regulations relating to animal welfare during transport (O J L340/91, O J L148/95, O J L0174/97, O J L052/98, O J L082/98)

- Application of EU regulations relating to animal welfare in slaughter house depots and slaughtering methods (O J L137/98, O J L340/93).

Significance of the application of these EU regulations and directives is to provide minimum demands relating to welfare of certain animal species and in this way reduce stress factors which are especially damaging in production of beef. Meat obtained from stressed animals has special characteristics (dark, firm, dry) - so called DFD meat. DFD-meat, as consequence of stress (Salye 1953), doesn't have the traits of normal meat. Main reason of rejections from foreign buyers is colour of meat. Dark appearance of DFD meat is consequence of used muscle glycogen due to the effect of stress factors on organism immediately prior to slaughtering. Results of the research on correlation between colour of meat and $\mathrm{pH}$ value (Price and Tennessen, 1981; Aleksić, 1986, 1995) indicate that there is direct effect of $\mathrm{pH}_{24}$ on meat colour. Many authors - meat scientists, (Lawrie, 1966; Lister 1981, Aleksić, 1986, 2000) as proof of their statement that colour of meat depends on $\mathrm{pH}$ value state the fact that perigoral meat treated with buffer of $\mathrm{pH}$ value 7,0 becomes even more dark and if the same meat is treated with buffer of $\mathrm{pH}=5,3$ light colour of meat is obtained, (Freeden et al., 1974). Second reason for rejection of carcasses with DFD traits by foreign buyers 
is firmness. Specific firmness of DFD meat is caused by its great water binding capacity (WBC) (Lawrie, 1966; Fischer, 1981; Aleksic 1985, 1992, 1995). High $\mathrm{pH}_{24}$ value of DFD meat doesn't allow the degradation of formed actomyosin complex resulting in firm consistency of DFD meat. Water binding capacity (WBC) of meat is culinary and technological trait which in normal circumstances would determine the choice of optimal processing method of meat. DFD-meat has greater water binding capacity (Aleksić 1986, 1991, 1995, Cornfort and Egbert, 1985). Dransfield, (1981) who concluded that DFD meat has more gentle structure but poor taste and aroma compared to normal meat. Occurrence of DFD meat is characteristic for all countries with intensive livestock production and DFD meat is by 10 to $30 \%$ cheaper than normal meat (Aleksic et al., 1992). Modern meat science is investigating the effect of stress prior to slaughtering since it is thought that only healthy animals provide meat of necessary quality. Therefore it is necessary to reduce stress factors to minimum, especially stress factors prior to slaughtering (Aleksić, 1995, 2003).

\title{
Conclusion
}

Considering the needs of developed countries in regard to import of high quality beef, Republic of Serbia has to provide in fast and efficient way sufficient quantities of meat of top quality in the near future. Beside application of EU regulations and standards aiming to reduce the stress factors it is necessary to provide high quality fattening material - female calves for production of "baby beef" type and bull claves for prolonged fattening. Contrary to increased demand for fattening heads of cattle there is trend of decrease of number of calves and young bulls. There are approx. 750.000 cows and heifers in Serbia today (Rep. Bureau of Statistics). Domestic Spotted breed of Simmental type participates with 50\% and Domestic Spotted cattle with lower productive traits with $40 \%$, remaining $10 \%$ are other breeds and crosses.

One of the efficient ways for production of high quality and quantity of calves is by method of industrial crossing of cattle of Domestic Spotted breed of lower productive traits. Based on our research results and results obtained by other authors crosses obtained by crossing with French meat breeds have achieved considerably better results in traits of daily gain (Čobić, 1990, Kunzi, 1978, Medić, 1989, Vasović, 1990, Lazarević, 1988, 1994, Miščević, 2000, Aleksić, 1996, 1997), meat yield-dressing percentage (Lazarević, 1992, Miščević, 1997, Aleksić 1998, 2000) and meat quality (Čepin, 2001, Aleksić,1996, 1999, Nosal, 1992, Augustini, 1989). Other method for improvement of production of calves for fattening is insemination of one part of population with semen from Simmental bulls positively tested on fattening traits in order to improve existing cattle types for production of meat (Aleksić, 1996, 1999).

Based on obtained results and realized economical effects we can recommend the method of industrial crossing for $20-25 \%$ of female breeding population of Domestic spotted breed (Aleksić, 1995, 1997). At the same time, high quality meat from crosses of F1 generation will completely satisfy the requirements of consumers, especially traditional importers of our meat (Italy and Greece).

\section{PROIZVODNJA KVALITETNOG JUNEĆEG MESA U SKLADU SA EVROPSKIM TRENDOVIMA}

\author{
S. Aleksić, , M. M. Petrović, B. Miščević, V.Pantelić, Dušica Tomašević, Dušica Ostojić
}

\section{Rezime}

U našoj zemlji tov junadi se uglavnom zasniva na grlima domaće šarene rase. Budućnost srpskog izvoza mesa leži pre svega u proizvodnji junećeg mesa takvog kvaliteta koji odgovara zahtevima odgovarajućeg tržišta. U tom smislu na osnovu našeg dosadašnjeg iskustva i prakse proizvodnje junećeg mesa za poznate kupce i tržišta a prema njihovom zahtevu možemo podeliti u tri grupe i to: za italijansko, grčko i ostala tržišta. Preduslov za bilo kakav izvoz junećeg mesa je: identifikacija i registracija svih goveda na teritoriji $\mathrm{R}$ Srbije, primena međunarodnih standarda kontrole praćenja procesa proizvodnje $\mathrm{i}$ primena regulativa EU koji se odnose na dobrobit životinja u cilju minimiziranja stres faktora, a samim tim i trupova sa simptomima DFD mesa. Pored preduslova primene regulativa i standarda EU potrebno je obezbediti kvalitetan tovni materijal odnosno ženska telad za prozvodnju tipa "baby beef" a muška za produženi tov. 
Nasuprot povećanim potrebama za grlima za tov, imamo opadanje broja teladi i junadi. Jedan od načina brze i efikasne prozvodnje kvalitetne teladi za tov je primena metode industrijskog ukrštanja goveda domaće šarene rase nižih proizvodnih osobina. $\mathrm{Na}$ osnovu dobijenih rezultata i ostvarenih ekonomskih efekata možemo preporučiti da se metodom industrijskog ukrštanja treba obuhvatiti $20-25 \%$ plotkinja od ukupne populacije domaće šarene rase. Istovremeno, kvalitete mesa meleza F1 generacije u potpunosti zadovoljava sve zahteve potrošača, posebno onih (Italija, Grčka i dr.) koji su tradicionalni uvoznici našeg junećeg mesa.

Ključne reči: Goveda, regulative EU, stres, ukrštanje, rasa, ekonomski efekti.

\section{Literature}

1. ALEKSIĆ S. (1985): Preventivno tretiranje mladih bikova pre klanja u cilju minimiziranja DFD-mesa. Knjiga: "Postmortalne promene mesa, elektrostimulacija i DFD-meso" Prvi jugolovenski naučni skupNIM-1984, Subotica. Jugoslovenski institut za tehnologiju mesa,

2. ALEKSIĆ S., NEGOVANOVIĆ D., AZANJAC N. (1991): Neka biohemijska i strukturna svojstva DFDmesa mladih bikova. I naučni skup prehrambenih tehnologa Srbije. Poljoprivredni fakultet, Beograd, Zbornik radova.

3. ALEKSIĆ S., LAZAREVIĆ R., VASOVIĆ S., RADOSAVLJEVIĆ D., MIŠČVIĆ B. (1992).: Stres sindrom junadi. Poljoprivreda, 362-363.

4. ALEKSIĆ S., LAZAREVIĆ R., JOVANOVIĆ S., MIŠČEVIĆ B., PETROVIĆ M. (1995): Uticaj tovilišta, dužine transporta $\mathrm{i}$ dužine odmora pre klanja na kvalitet mesa junadi. Biotehnologija $\mathrm{u}$ stočarstvu, 3-6..

5. ALEKSIĆ S. R. LAZAREVIĆ, B. MIŠČEVIĆ, PETROVIĆ M.M., JOSIPOVIĆ S. (1995): Proizvodni i ekonomski aspekti ukrštanja domaće šarene rase sa francuskim tovnim rasama. Tehnologija mesa 2-3, god. XXXVI, 77-79.

6. ALEKSIĆ S., LAZAREVIĆ R., MIŠČEVIĆ B., JOSIPOVIĆ S., PETROVIĆ M.( 1996) :Carcass composition of young domestic simental breed with different body weight. $47^{\text {th }}$ Annual Meeting of the European Association for Animal Production, Lillehammer, Norway, p.200.

7. ALEKSIĆ S. R. LAZAREVIĆ, B. MIŠČEVIĆ, PETROVIĆ M.M., JOSIPOVIĆ S. (1997): Nove tehnologije za povećanje prinosa i kvaliteta junećeg mesa domaće šarene rase namenjenog izvozu. Biotehnologija u stočarstvu, posebna edicija, p 17-24.

8. ALEKSIĆ S. R. LAZAREVIĆ, B. MIŠČEVIĆ, PETROVIĆ M.M., JOSIPOVIĆ S. (1998): Fiksni uticaj genotipa na kvalitet junećeg mesa. Biotehnologija u stočarstvu, 1-2, p 31-39.

9. ALEKSIĆ S., MILICA VLAHOVIĆ, B. MIŠČEVIĆ, M. PETROVIĆ, S. PERKOVIĆ (1999):The correlation between the distribution of carcass fatty tissue traits of meat in different genotypes of young bulls. Biotehnology in Animal Husbandry (5-6), p.1-7.

10. ALEKSIĆ S., LAZAREVIĆ R., MIŠČEVIĆ B., M. PETROVIĆ, S. JOSIPOVIĆ (2000):The investigation of the technological traits of beef with DFD symptoms. Biotehnology in Animal Husbandry Vol. 16, (3-4), p. 55-63.

11. ALEKSIĆ S., LAZAREVIĆ R., MIŠČEVIĆ B., M. PETROVIĆ, DUŠICA TOMAŠEVIĆ (2001): The effect of Live Weight Prior to Slaughtering on Yield and Weight of Retail Carcass Cuts. Biotechnology in Animal Husbandry 17(5-6), p. 125-133..

12. ALEKSIĆ S, MISCEVIĆ B., M.M.PETROVIĆ, ZLATICA PAVLOVSKI, S. JOSIPOVIĆ, DUŠICA TOMAŠEVIĆ (2002): Investigation of factors affecting the results regarding the dressing percentage value of male young cattle of domestic Simmental breed and crossbreds of Domestic Simmental and Limousine breed, Biotechnology in Animal Husbandry 18(3-4), p: 9-15.

13. ALEKSIĆ S., MISCEVIĆ B., M.M.PETROVIĆ, ZLATICA PAVLOVSKI, S. JOSIPOVIĆ, DUŠICA TOMAŠEVIĆ (2003): The possibility of preventing stress syndrome in young bulls. Biotechnology in Animal Husbandry, Vol 19, 5-6, p.79-85.

14. AUGUSTINI, CHR., TEMISAN, V. (1989): Uticaj namenskog ukrštanja na kvalitet trupova zaklanih životinja i kvalitet mesa. Tehnologija proizvodnje i kvalitet goveđeg mesa. Tehnološki fakultet, Novi Sad,p.9-16.

15. CORNFORTH D.P., W.R.EGBERT (1985): Efect of rotenone and $\mathrm{pH}$ on the colour of pre-rigor muscle. Journal Food Science. 
16. DRANSFIELD E. (1981): Eatinig quality of DFD-beef. The Problem of Dark-cutting in Beef, Martinus Nijhoff Publishers.

17. DAVEY C.L., GRAAFHUIS A.E. (1981): Early identification of the DFD condition in pre-rigor beef carcasses. The Problem of Dark Cutting in Beef, Martinus Nijhoff Publishers,.

18. FREEDEN H.T., A.H.MARTIN, G.M.WEISS (1974) Changes in tenderness of beef longissimus dorsi as related to muscle colour and $\mathrm{pH}$. J.Fd.Sci., 39, 533.

19. GILL C.O., NEWTON K.G. (1981): Microbiology of DFD-meat. The Problem of Dark Cutting in Beef, Martinus Nijhoff Publishers.

20. ČEPIN S. (2001) : Blagovne znamke govjega mesa. Meso in mesnine, br. Vol. 2, p. 17-20.

21. ČOBIĆ T., NENADOVIĆ M., MEDIĆ D., NOVAKOVIĆ M. (1990): Ispitivanje tovnih sposobnosti muških meleza $F_{1}$ generacije šaroleske $\mathrm{i}$ limuzinske sa simentalskom rasom goveda. Biotehnologija $u$ stočarstvu, 3-4, pp 3-13.

22. KUNZI, N., GAILLARD, S., LEUENBERGER, H., SCHNEEBERGER, N., WEBER, F. (1978): Beef breeds bulls versus selected dual purpose bulls in producing calves for meat production. Livestock Production Science. Vol. 5, No.3.

23. LAZAREVIĆ, R. (1988): Francuske tovne rase za poboljšanje mesa domaćeg šarenog govečeta. Monografija, Ekonomika poljoprivrede, Beograd.

24. LAZAREVIĆ, R., VASOVIĆ, S., LAZAREVIĆ, LJ., JOSIPOVIĆ, S., ALEKSIĆ, S., MIŠČEVIĆ, B. (1992): Unapređenje proizvodnje mesa goveda ukrštanjem. Biotehnologija u stočarstvu, 5-6.

25. LAZAREVIĆ, R., JOSIPOVIĆ, S., AĐIĆ, N., VASOVIĆ, S., MIŠČEVIĆ, B., PETROVIĆ, M., ALEKSIĆ, S. (1994): Efficiency regardinig of the utilazition of genomes of fattening and combined breeds in beef production in condition of extensive fattening. Biotehnologija u stočarstvu, 3-4.

26. LAWRIE R.A.(1965): Metabolic stress which affect muscle. The Univ. of Wisconsin, Proceeding of an International Symposium.

27. MIŠČEVIĆ M., LAZAREVIĆ R., ALEKSIĆ S. , PETROVIĆ M.M., JOSIPOVIĆ S. (1997): Fiksni uticaj genotipa na proizvodne osobine junadi. Biotehnologija u stočarstvu, 3-4, pp 65-73

28. MIŠČEVIĆ B., R. LAZAREVIĆ, S. ALEKSIĆ, M.M.PETROVIĆ, S. JOSIPOVIĆ (2000):Evaluation of the genetics parameters of fattening traits of young cattle of different genotypes. Biotehnology in Animal Husbandry Vol. 16, (1-2), p.19-24.

29. NOSAL, V., ČUBON, J. (1992): Structure of carcass and meat quality in heifers-products of commercial crossing with meaty breeds. Biotehnologija u stočarstvu, 5-6, p.55-59.

30. Offical Journal L 323, (1978), European Convention for the protection of animals kept for farming purposes, p.14-22.

31. Offical Journal L 323, (1978), Counsil Decision concering the conclusion of the European Convention for the protection of animals kept for farming purposes, p.12-13.

32. Offical Journal L 019, (2000), Commision Decision concering minimum requirements for the inspection of holding on which animals are kept for farming purposes, p.51-53.

33. Offical Journal L 221, (1998), Council Directive concering the protection of animals kept for farming purposes, p 23-27.

34. Offical Journal L 340, (1991), Council Directive laying dowen minimum standards for the protection of calves, $\mathrm{p}$ 28-32.

35. Offical Journal L 025, (1997), Council Directive laying dowen minimum standards for the protection of calves, $\mathrm{p}$ 24-25.

36. Offical Journal L 076, (1997), Council Directive laying dowen minimum standards for the protection of calves, $\mathrm{p}$ 30-30

37. Offical Journal L 137, (1988), European Convention for the protection of animals for slaughter, p.27-38.

38. Offical Journal L 137, (1988), Counsil Decision on the conclusion of the European Convention for the Protection of animals for Slaughter, p.25-26.

39. Offical Journal L 340, (1993), Council Directive on the protection of animals at the time of slaughter or killing, p 17-27.

40. Offical Journal L 340, 1991, Council Directive on the protection of animals during transport, p. 21-34.

41. Offical Journal L 148, (1995), Council Directive on the protection of animals during transport, p. 52-63.

42. Offical Journal L 174, (1997), Council Regulation concering Community criteria for staging point and amending route plan, p. 1-6. 
43. Offical Journal L 052, 1998., Council Regulation on additional animal protection standards applicable to road vehicles used for carriage of livestock on journeyes exceeding eight hours, p. 8-8.

44. PRICE J.F. TENNESEN T. (1981): Pre-slaughter managment and dark-cutting in the carcasses of young bulls, Canadian Journal of Animal Science, 61.

45. PUOLANNE E., AALTO H. (1981): The incidence of dark-cutting in young bulls in Finland. The Problem of Dark-cutting in Beef, Martinus Nijhoff Publishers.

46. Republički Zavod za statistiku (2005) br.70 LIV.

47. SELEY H. (1953): Lehre von Adaptions syndrom, Georg Thiem, Stutgart.

48. TOJAGIĆ S., RADOJČIĆ Đ. (1989): Značaj proizvodnje kvalitetnog junećeg mesa.Tehnologija proizvodnje i kvalitet goveđeg mesa, Zbornik, Tehnološki fakultet, N. Sad, p1-8.

49. VASOVIĆ, S., LAZAREVIĆ, R., MITIĆ, LJ., PETROVIĆ, M., JOSIPOVIĆ, S., MIŠČEVIĆ, B.(1990): Ispitivanje nekih tovnih osobina junadi F1 generacije iz ukrštanja domaćeg šarenog govečeta sa francuskim tovnim rasama. Biotehnologija u stočarstvu, 3-4. 